\title{
PERAN JAKSA AGUNG REPUBLIK INDONESIA TERHADAP PEMBENTUKAN DAN PELAKSANAAN TUGAS TIM PENGAWALAN, PEMERINTAH DAN PEMBAGUNAN DAERAH
}

\author{
Oleh: \\ Mhd Taufiqurrahman \\ Universitas Darma Agung \\ E-Mail : \\ Mhd.taufiqurrahman08@yahoo.co.id
}

\begin{abstract}
This discussion dealt with The Role of the Attorney General of the Republic of Indonesia in the Formation and Implementation of the Duty of the Guards, Safeguards of Government and Regional Development Team (TP4D). The problems of the study discussed in this research were what the legal arrangement of the Guards, Safeguards of Government and Regional Development Team (TP4D) was and what the role of the prosecutors in Guards, Safeguards of Government and Regional Development Team (TP4D) was. The research method used with the type of research used was empirical legal research. Empirical legal research is a legal research method that functions to be able to see the law in the real sense and examine how the law works in a community environment. The specification of this research is descriptive, with the intention to describe the existing conditions by using scientific research methods and solving problems based on data and facts collected as they were at the time the research was conducted. The conclusion in the discussion was that the President Instruction No. 1 of 2016 concerning the Acceleration of the Implementation of National Strategic Projects was not only addressed to the Ministers of the Work Cabinet, Cabinet Secretary, the Chief of the President Staff, the Heads of Non-Ministry Government Agencies, Governors and Regents / Mayors, but also instructed to the General Attorney of the Republic of Indonesia and the Head of the Indonesian National Police. To fight the stigma of criminalizing the policy that made the bureaucratic officials and businessmen afraid and hesitant in making decisions on accelerating the development and the strategies of national development programs, the Guards, Safeguards of Government and Regional Development Team (TP4D) was formed based on the decision of the Attorney General of the Republic of Indonesia No. KEP-152 / A / JA / 10/2015 dated October 1, 2015 concerning the establishment of the Guards, Safeguards of Government and Regional Development Team (TP4D) of the Republic of Indonesia which have the duties: to guard, secure and support the success of the running of the government and development through prevention / preventive and persuasive efforts in the jurisdiction of the Prosecutor's Office. While it was expected that the budget absorption was running normally for the benefit of the programs of national development. It was expected that resolutions of the existing problems with policies and officials will use the Government Administration process in accordance with the provisions of Law No. 30 of 2014 concerning Government Administration,
\end{abstract}

Keywords: Guards, Safeguards of Government and Regional Development Team (TP4D), General Attorney Office,

\section{PENDAHULUAN}

Salah satu tindak pidana yang fenomenal adalah tindak pidana korupsi. Dampak negatif yang ditimbulkan oleh tindak pidana ini dapat menyentuh berbagai bidang 
kehidupan. Tindak pidana korupsi di Indonesia sudah semakin meluas dan tidak terkendali dikalangan masyarakat Indonesia yang akan membawa bencana pada kehidupan berbangsa dan bernegara. Meningkatnya kasus tindak pidana korupsi merupakan masalah yang sangat serius, karena tindak pidana korupsi dapat membahayakan stabilitas dan kemanan negara dan masyarakatnya, membahayakan pembangunan 128ersua dan ekonomi masyarakat, politik, bahkan dapat pula merusak nilai-niai demokrasi serta moralitas bangsa karena korupsi merupakan ancaman terhadap cita-cita menuju masyarakat yang adil dan makmur. Menyadari kompleksnya permasalahan korupsi di tengahtengah krisis multidimensional serta ancaman nyata yang pasti akan terjadi, maka tindak pidana korupsi dikategorikan sebagai salah satu kejahatan luar biasa (extra ordinary crime) yang pada saat ini dipandang lebih berbahaya bagi masa depan suatu bangsa dibanding kejahatan luar biasa lainya seperti penyalahgunanaan narkotika dan terorisme. Selain itu dalam dunia internasional korupsi dikategorikan sebagai kejahatan terhadap kemanusiaan (Crimes Against Humanity), dengan demikian penanggulangan korupsi harus dilakukan dengan aspek yuridis yang luar biasa (Extra Ordinary Enforcement) dan tindakan-tindakan yang luar biasa pula (Extra Ordinary Measures).

Salah satu tipe korupsi yang bersumbangsi besar dalam terjadinya peningkatan tindak pidana korupsi adalah tindak pidana korupsi penyalahgunaan kewenangan, Tipe ini tercantum pada Pasal 3 UU No. 31 Tahun 1999 sebagaimana diubah dan di perbaharui dengan UU No.20 Tahun 2001 Tentang Perubahan Atas UU
No.31 Tahun 1999 Tentang Pemberantasan Tindak Pidana Korupsi (PTPK).

Pada saat ini penyalahgunaan kewenangan yang berimplikasi pada terjadinya tindak pidana korupsi paling banyak terjadi karena pelakunya bukan hanya berasal dari orang-orang yang menduduki jabatan/kedudukan strategis dalam 128ersua pemerintahan dan kenegaraan yang berada di ibukota Negara, namun, tipe korupsi ini telah menjalar hingga ke pelosokpelosok daerah yang dilakukan oleh pejabat-pejabat daerah. Bahkan yang lebih memprihatinkan yakni bahwa korupsi tipe ini telah merambah hingga ke tataran desa yakni pemerintahan desa yang dipimpin oleh seorang kepala desa.

Maupun pembangunan

infrastruktur. Di sisi lain, pemerintah juga memerlukan barang dan jasa itu dalam melaksanakan kegiatan pemerintahan. Pemenuhan kebutuhan barang dan jasa merupakan bagian yang penting dalam penyelenggaraan pemerintahan.

Dalam rangka penyelenggaraan negara yang bersih dari korupsi, kolusi dan nepotisme, maka Presiden RI Joko Widodo membuat agenda prioritas dalam menjalankan roda pemerintahan yang tercantum di dalam 9 (128 ersuasi) Agenda Prioritas yang disebut dengan Nawa Cita.

Sebagai tindak lanjut dari 9 (128ersuasi) Agenda Prioritas Nawa Cita, maka Presiden mengeluarkan Instruksi Presiden Nomor 7 Tahun 2015 tentang Aksi Pencegahan dan Pemberantasan Korupsi Tahun 2015 pada tanggal 6 Mei 2015. Instruksi Presiden Nomor 7 Tahun 2015 tentang Aksi Pencegahan dan Pemberantasan Korupsi Tahun 2015 dimaksudkan untuk meningkatkan upaya pencegahan terjadinya tindak 
pidana korupsi di instansi pemerintahan yang perlu didukung dan dilaksanakan secara terencana dan sungguh-sungguh sehingga kegiatan pencegahan korupsi yang dilakukan oleh Kejaksaan Republik Indonesia dapat berlangsung dengan efektif dan optimal.

$$
\text { Dari adanya Instruksi }
$$

Presiden Nomor 7 Tahun 2015 ini, maka Kejaksaan Republik Indonesia memandang perlu memberikan pendampingan kepada pejabat pemerintahan terkait dalam hal akselerasi pembangunan dan program-program strategis pembangunan nasional.

Di samping itu, Kejaksaan Republik Indonesia sebagai lembaga penegak hukum berperan dalam mendukung keberhasilan penyelenggaraan pemerintahan dan pembangunan nasional di pusat dan daerah melalui pengawalan dan pengamanan, baik dalam kegiatan perencanaan, pelaksanaan maupun pemanfaatan hasil pembangunan, termasuk dalam upaya mencegah timbulnya penyimpangan dan kerugian negara. Melihat hal tersebut, maka

Kejaksaan Republik Indonesia mengeluarkan Keputusan Jaksa Agung Republik Indonesia Nomor: KEP-152/A/JA/10/2015 tentang Pembentukan Tim Pengawal, Pengaman Pemerintahan dan Pembangunan (TP4) Kejaksaan Republik Indonesia.

Dalam rangka melaksanakan Keputusan Jaksa Agung Republik Indonesia Nomor: KEP152/A/JA/10/2015 tentang Pembentukan Tim Pengawal, Pengaman Pemerintahan dan Pembangunan (TP4), maka Kejaksaan Republik Indonesia juga mengeluarkan Instruksi Jaksa Agung Republik Indonesia Nomor: INS001/A/JA/10/2015 tentang Pembentukan dan Pelaksanaan Tugas Tim Pengawal, Pengaman
Pemerintahan dan Pembangunan Pusat (TP4P) dan Daerah (TP4D).

\section{METODE PELAKSANAAN}

\section{Pendekatan Penelitian}

Dalam penelitian ini, jenis penelitian yang digunakan adalah penelitian hukum empiris. Penelitian hukum empiris adalah suatu metode penelitian hukum yang berfungsi untuk dapat melihat hukum dalam artian nyata serta meneliti bagaimana bekerjanya hukum di suatu lingkungan masyarakat, maka metode penelitian hukum empiris dapat juga dikatakan sebagai penelitian hukum sosiologis.

\section{Spesifikasi penelitian}

Penelitian ini bersifat Deskriptif, dengan maksud untuk menggambarkan keadaan yang ada dengan mempergunakan metode penelitian ilmiah serta memecahkan masalah berdasarkan data dan fakta yang terkumpul sebagaimana adanya pada saat penelitian ini dilakukan.

\section{Jenis dan Sumber Data}

1) Bahan hukum primer, yaitu bahan hukum yang mempunyai kekuatan mengikat yaitu berupa peraturan perundangundangan.

2) Bahan hukum sekunder, yaitu bahan hukum yang memberikan penjelasan bahan hukum primer yang terdiri dari: literature, makalah, jurnal, artikel, internet dan hasil penelitian yang berhubungan dengan masalah penelitian ini.

3) Bahan hukum tertier, yaitu bahan hukum yang 
memberikan penjelasan bagi bahan hukum primer dan bahan hukum sekunder seperti kamus dan ensiklopedia.

Berdasarkan latar belakang di atas, maka garis besar yang menjadi rumusan masalahnya adalah :

1. Bagaimana pengaturan hukum Tim Pengawal, Pengaman Pemerintahan dan Pembangunan Daerah (TP4D) ?

2. Bagaimana Peran Kejaksaan Tim Pengawal, Pengaman Pemerintahan dan Pembangunan Daerah (TP4D) ?

\section{HASIL DAN PEMBAHASAN}

\section{A. Pengaturan Hukum Tim Pengawal Pengaman Pemerintahan dan Pembangunan (TP4)}

Fenomena akan rendahnya penyerapan anggaran dan perlambatan pertumbuhan ekonomi, yang antara lain melatarbelakangi Presiden Joko Widodo untuk melakukan pertemuan dengan seluruh Gubernur, Kepala Kejaksaan Tinggi (Kajati) dan Kepala Kepolisian Daerah (Kapolda) dalam rapat koordinais di Istana Bogor, pada tanggal 24 Agustus 2015. Dalam kesempatan itu, Presiden Joko Widodo mengingatkan semua jajaran pemerintah untuk melakukan langkah antisipasi akan terjadinya perlambatan ekonomi, termasuk permasalahan pada serapan dan belanja anggaran, baik APBN, APBD Provinsi, Kota/Kabupaten, maupun BUMN.

Setidaknya ada beberapa susbtansi instruksi Presiden yang dialamatkan ke aparat penegak hukum, antara lain:

1. Aparat penegak hukum untuk tidak mudah memidanakan kebijakan yang diambil oleh pejabat negara dan pejabat daerah supaya program-program pembangunan tidak terhambat
2. Aparat penegak hukum tidak boleh langsung menindaklanjuti hasil audit Badan Pemeriksa Keuangan (BPK). Apabila terdapat temuan BPK, maka diberikan waktu selama 60 hari untuk melakukan klarifikasi dan tindak lanjut oleh para kepala kementerian atau gubernur, bupati/walikota. Oleh karena itu, aparat penegak hukum tidak boleh mengintervensi dalam proses klarifikasi itu

3. Penyeragaman pandangan dan persepsi antara penegak hukum dengan auditor (BPK dan BPKP) tentang kerugian negara dan potensi kerugian negara. Dalam hal ini, kerugian negara harus benar-benar jelas dan kongkrit berupa penyimpangan anggaran APBN/APBD yang digunakan untuk kepentingan pribadi atau pihak-pihak tertentu yang bertentangan dengan hukum

Nampaknya percepatan pembangunan sebagimana yang dicanangkan pemerintah, tidak berjalan sesuai dengan harapan. Masih banyak dijumpai berbagai kendala dalam pelaksanaan pembangunan infrastruktur dan proyek-proyek strategis lainnya, baik dalam tahap penyiapan, pengadaan dan pendanaan proyek, pelaksanaan pembangunan fisik, pengawasan dan pengendalian, termasuk berbagai persoalan hukum.

Dalam rangka untuk mempercepat pelaksanaan pembangunan, kemudian Presiden Joko Widodo pada tanggal 8 Januari 2016 mengeluarkan instruksi Presiden No. 1 Tahun 2016 tentang Percepatan Pelaksanaan Proyek Strategis Nasional. Inpres I tahun 2016 tersebut tidak hanya ditujukan kepada para Mentri Kabinet Kerja, Sekretaris Kabinet, Kepala Staf Kepresidenan, para Kepala Lembaga Pemerintah Non Kementerian, para 
Gubernur dan para Bupati/Walikota, melainkan juga dinstruksikan kepada Jaksa Agung Republik Indonesia dan Kepala Kepolisian Negara Republik Indonesia.

Hal-hal yang menjadi instruksi Presiden kepada Jaksa Agung dan Kapolri dalam Inpres 1 Tahun 2016 adalah,

1. Mendahulukan proses administrasi pemerintahan sesuai ketentuan UndangUndang Nomor 30 Tahun 2014 tentang Administrasi Pemerintahan sebelum melakukan penyidikan atas laporan masyarakat yang menyangkut penyalahgunaan wewenang dalam pelaksanaan Proyek Strategis Nasional.

2. Meneruskan/menyampaikan laporan masyarakat yang diterima oleh Kejaksaan Agung Republik Indonesia atau Kepolisian Negara Republik Indonesia mengenai penyalahgunaan wewenang dalam pelaksanaan Proyek Strategis Nasional kepada pimpinan

kementerian/lembaga atau Pemerintah Daerah untuk dilakukan pemeriksaan dan tindak lanjut penyelesaian atas laporan masyarakat, termasuk dalam hal diperlukan adanya pemeriksaan oleh Aparat Pengawasan Intern Pemerintah.

3. Melakukan pemeriksaan atas hasil audit Aparat Pengawasan Intern Pemerintah mengenai temuan tindak pidana yang bukan bersifat 131ersuasive131ive yang disampaikan oleh pimpinan kementerian/lembaga atau Pemerintah Daerah sesuai ketentuan peraturan perundang-undangan.

4. Melakukan pemeriksaan atas hasil audit Aparat Pengawasan Intern Pemerintah sebagaimana dimaksud pada angka 3, dengan berdasarkan:
a. Asas-Asas Umum
Pemerintahan yang Baik;
b. Alasan yang objektif;
c. Tidak menimbulkan konflik kepentingan; dan
d. dilakukan dengan iktikad baik.

5. Tidak mempublikasikan pemeriksaan secara luas kepada masyarakat sebelum tahapan penyidikan.

6. Menggunakan pendapat dan/atau penjelasan/keterangan ahli dari kementerian/lembaga yang berwenang sebagai tafsir resmi dari peraturan perundangundangan terkait.

7. Menyusun peraturan internal mengenai tata cara (Standar Operasional dan Prosedur/SOP) penanganan laporan masyarakat yang menyangkut penyalahgunaan wewenang dalam pelaksanaan Proyek Strategis Nasional sebagai dasar pelaksanaan tugas di masingmasing jajaran unit instansi 131ersuasi.

8. Memberikan pendampingan/pertimbangan hukum yang diperlukan dalam percepatan pelaksanaan proyek strategis nasional.

9. Melakukan pembinaan dan pengawasan terhadap jajaran dibawahnya dan memberikan tindakan apabila terdapat penyimpangan dan pelanggaran.

Poin terpenting yang patut dicatat dalam Inpres 1 Tahun 2016 terkait dengan penegakan hukum agar mendahulukan proses Administrasi Pemerintahan dalam melakukan pemeriksaan dan penyelesaian atas laporan penyalahgunaan wewenang dalam pelaksanaan Proyek Strategis Nasional. Ini menunjukkan bahwa melalui Inpres No. 1 Tahun 2016, Presiden menginginkan agar proses 
penegakan hukum ditempatkan sebagai ultimum remeddium, setelah upaya-upaya pencegahan dan tindakan administrasi dilakukan.

Keinginan Presiden untuk mengedepankan proses administrasi, terlihat pula dari Peraturan Presiden Republik Indonesia (Perpres) Nomor 3 Tahun 2016 tentang Percepatan Pelaksanaan Proyek Strategis Nasional. Secara jelas ketentuan Pasal 31 ayat (1) Pepres No. 3 Tahun 2016 menyebutkan:

Dalam hal terdapat laporan dan/atau pengaduan dari masyarakat kepada pimpinan kementrian/lembaga, gubernur atau bupati/walikota sebagai pelaksana Proyek Strategis Nasional atau kepada Kejaksaan Agung atau Kepolisian Negara Republik Indonesia mengenai penyimpangan atau penyalahgunaan wewenang dalam pelaksanaan Proyek Strategis Nasional, penyelesaian dilakukan dengan mendahulukan proses administrasi sesuai dengan ketentuan peraturan perundangan di bidang administrasi pemerintahan.

Terhadap laporan atau pengaduan masyarakat yang disampaikan kepada aparat penegak hukum, terlebih dahulu Kejaksaan dan Polri menyampaikan kepada pimpinan kementrian/lembaga, gubernur atau bupati/walikota untuk dilakukan pemeriksaan. Jangka waktu tindak lanjut penyelesaian atas laporan atau pengaduan masyarakat itu selama 5 (lima) hari, sejak laporan masyarakat diterimanya.

Setelah dilakukannya pemeriksaan awal dan ditemukan adanya indikasi penyalahgunaan wewenang, maka pimpinan kementrian/lembaga, gubernur atau bupati/walikota meminta Aparat Pengawasan Intern Pemerintah (APIP) untuk melakukan pemeriksaan/audit lebih lanjut paling lama dalam waktu 30 (tiga puluh) hari kerja. Adapun wujud dari hasil pemeriksaan APIP dapat berupa : a. Kesalahan administrasi yang tidak menimbulkan kerugian Negara, yang penyelesaiannya dilakukan melalui peyempurnaan administrasi paling lama 10 (sepuluh) hari kerja sejak hasil pemeriksaan APIP disampaikan;

b. Kesalahan administrasi yang menimbulkan kerugian negara, yang penyelesaiannya dilakukan melalui penyempurnaan administrasi dan pengembalian kerugian negara paling lama 10 (sepuluh) hari kerja sejak hasil pemeriksaan APIP disampaikan ; atau

c. Tindak pidana yang bukan bersifat 132Admnistratif

Terhadap hasil pemeriksaan APIP berupa tindak pidana yang bukan bersifat 132Administratif, pimpinan kementrian/lembaga, gubernur atau bupati/walikota dalam jangka waktu paling lama 5(lima) hari kerja menyampaikan kepada Kejaksaan Agung atau Polri.

Ketentuan Perpres Nomor 3 tahun 2016 tersebut, telah mempertegas posisi APIP sebagai garda terdepan sekaligus filter dalam menindaklanjuti laporan atau pengaduan masyarakat. Kejaksaan dan Polri baru dapat melakukan

penyelidikan/penyidikan apabila hasil pemeriksaan APIP merupkan tindak pidana.

Mencermati ketentuan normative dalam Perpres Nomor 3 Tahun 2016, setidaknya terdapat 226 (duaratus duapuluh enam) proyek strategis nasional yang tidak dapat ditindaklanjuti langsung oleh aparat penegak hukum ketika adanya laporan atau pengaduan masyarakat. Proyek-proyek strategis nasional itu tersebar di berbagai daerah, yang terbagi dalam 24 (duapuluh empat) sector yaitu: 
1. Proyek Pembangunan Infrastruktur Jalan Tol;

2. Proyek Pembangunan Infrastruktur Jalan Nasional/Strategis Nasional Non-Tol;

3. Proyek Pembangunan Infrastruktur Sarana Dan PraSarana Kereta Api Antar Kota;

4. Proyek Pembangunan Infrastruktur Kereta Api Dalam Kota;

5. Proyek Revitalisasi Bandar Udara;

6. Proyek Pembanguna Bandar Udara Baru;

7. Proyek Bandar Udara Strategis Lainnya;

8. Peroyek Pembaunan Pelabuhan Baru Dan Pengembangan Kapasitas;

9. Program 1 Juta Rumah;

10. Proyek Pembangunan Kilang Minyak;

11. Proyek Pia Gas/Terminal Lpg;

12. Proyek Infrastruktur Energi Asal Sampah;

13. Proyek Infrastruktur Air Minum;

14. Proyek Penyediaan Infrastruktur Sistem Air Limbah Komunal;

15. Proyek Pembangunan Tanggul Penahan Banjir;

16. Proyek Pembangunan Pos Lintas Batas Negara Dan Sarana Penunjang;

17. Proyek Bendungan;

18. Program Peningkatan Jangkauan Broadband

19. Proyek Infrastruktur Iptek Strategis Lainnya;

20. Pembangunan Kawasan Industri Prioritas/Kawasan Ekonomi Khusus

21. Pariwisata

22. Proyek Pembangunan Smelter

23. Proyek Pertanian Dan Kelautan

24. Program Pembangunan Infrastruktur Ketenagalistrikan
Keinginan pemerintah untuk mengedepankan aspek 133Administratif, juga terlihat jelas dari instruksi Presiden yang ditujukan kepada Jaksa Agung dan Kapolri agar "mendahulukan proses administrasi peemrintahan sesuai ketentuan Undang-Undang Nomor 30 Tahun 2014 tentang administrasi Pemerintahan sebelum melakukan penyidikan atas laporan masyarakat yang menyangkut penyalahgunaan wewenang dalam pelaksanaan "Proyek Srategis Nasional". Setelah mendengar paparan Jaksa Agung dan Kapolri, serta mendengarkan saran Wakil Presiden, kemudian Presiden Joko Widodo memerintahkan agar Kajati dan Kapolda menyampaikan jajaran Kepala Kejaksaan Negeri (Kajari) dan Kepala Kepolisian Resor (Kapolres) beberapa poin penting yang telah disampaikan di Istana Kepresidenan Bogor pada tahun 2015, yaitu:

a. Kebijakan atau diskresi jangan dipidanakan;

b. Tindakan administrasi pemerintah jangan dipidanakan;

c. Kerugian negara harus konkrit, tidak dicari-cari dan tidak diada-adakan;

d. Untuk kerugian yang dinyatakan BPK, maka masih diberikan waktu 60 hari. Seluruh jajaran pemerintahan agar menghormati aturan main ini;

e. Tidak diekspos ke media secara besar-besaran, sebelum ada penuntutan.

Melihat kondisi seperti itu, Presiden mengingatkan bahwa tugas Kajati dan Kapolda adalah mengawal pembangunan. Apabila ketahuan jelas mencuri, apalagi tertangkap dalam Operasi Tangkap Tangan (OTT) maka 
penegak hukum dapat langsung memprosesnya dan tidak ada ampun kasus seperti itu. Namun untuk yang sifatnya kebijakan agar jangan dicaarai-cari kesalahannya, karena akan mrnyebabkan semua pihak ketakutan.

Tugas pemerintah adalah memperbaiki 134sistem dan apabila ada Bupati atau walikota yang terlihat akan melakukan kesalahan, untuk segera ditegur. Jangan dibiarkan kesalahannya sampai rampung, baru kemudian ditangkap. Tindakan seperti ini tidak akan memperbaiki system yang ada seperti ini tidak akan memperbaiki system yang ada saat ini, sehingga aparat penegak hukum jangan hanya berorientasi pada mengejar target kasus, baik perbulan maupun per tahun. Presiden meminta untuk membangun sebuah penegakan hukum yang menjamin kepastian hukum dan memenuhi rasa keadilan, karena itulah yang diperlakukan investor dalam melakukan investasinya di Indonesia.

Dalam hal ini, Presiden memerintahkan Jaksa Agung dan Kapolri untuk merubah 134ersuasi yang tidak mencaricari kasus atau perkara. Proses penegakan hukum agar didasarkan pada bukti-bukti yang kuat, sehingga tidak ada lagi kriminalisasi.

Mencermati political will pemerintah dan terjadinya pergeseran paradigma penegakan hukum, memperlihatkan akan semakin pentingnya aspek pencegahan sebagai bagian penting dalam pelaksanaan pembangunan. Sudah saatnya untuk menjadikan aparat penegak hukum sebagai mitra administrator pemerintahan, sehingga menjadi tidak relevan lagi ketika menempatkan keduanya secara diametral dan saling berhadapan. Oleh karenanya, hukum harus diproyeksikan sebagai pendukung pelaksanaan pembangunan dan aktivitas perekonomian lainnya untuk kesejahteraan manusia seutuhnya.

\section{B. Peran Kejaksaan Agung Tim Pengawal, Pengaman Pemerintahan dan Pembangunan Daerah (TP4D)}

Secara tegas political will pemerintah dalam penegakan hukum disampaikan Presiden Joko Widodo, ketika memberikan sambutan pada Hari Bhakti Adhyaksa (HBA) tanggal 22 Juli 2015 maupun pertemuan antara Presiden dan seluruh pimpinan kabinetnya di Bogor tanggal 25 Agustus 2015. Pada HBA Tahun 2015, Presiden Joko Widodo meminta Jaksa Agung untuk melakukan penegakan hukum tepat dan efektif guna mendukung program pembangunan nasional. Menurutnya, pemberantasan korupsi, penegakan hukum harus diletakkan pro rakyat dan mendukung program pembangunan nasional. Kejaksaan setidaknya dapat membantu birokrasi dalam mengembangkan inovasi dan kreativitas dalam pembangunan. Jangan sampai upaya pemberantasan korupsi dan penegakan hukum membuat pemerintah daerah dan pelaku bisnis tidak berani berinovasi. Pimpinan kejaksaan harus mendampingin pejabat pemerintahan untuk akselerasi pembangunan nasional.

Menindaklanjuti amanat Presiden tersebut, selanjutnya Jaksa Agung mengambil langkahlangkah strategis sebagai upaya untuk menyelaraskan antara 
penegakkan hukum dengan pelaksanaan pembangunan nasional. Dalam berbagai kesempatan, Jaksa Agung senantiasa memandang bahwa suksesnya pembangunan nasional bukanlah hanya menjadi tanggungjawab dari para pelaksana pekerjaan saja, namun harus juga didukung oleh lembaga penegak hukum termasuk Kejaksaan. Sikap dan pandangan Jaksa Agung tersebut sejatinya merupakan refleksi dari amanat regulasi sebagaimana yang ditegaskan dalam Penjelasan Undang-undang Nomor 16 Tahun 2014 tentang Kejaksaan RI. Intisari dari amanat regulasi itu, mengharuskan Kejaksaan untuk terlibat sepenuhnya dalam proses pembangunan, dengan turut menciptakan kondisi yang mendukung dan mengamankan pelaksanaan pembangunan dalam rangka mewujudkan masyarakat adil dan makmur berdasarkan Pancasila.

Dalam $\begin{array}{r}\text { rangka } \\ \text { menyelaraskan antar }\end{array}$
penegak hukum dengan pelaksana
pembangunan ditandai dengan
dikeluarkannya Keputusan Jaksa
Agung RI No. KEP-
152/A/JA/10/2015 tanggal 1
Oktober 2015 tentang

Pembentukan Tim Pengawal dan Pengaman Pemerintahan dan Pembangunan (TP4). Gagasan pembentukan TP4 merupakan jawaban atas keprihatinan Jaksa Agung, terhadap adanya pandangan pihak-pihak tertentu yang memandang Kejaksaan bukan sebagai mitra dan partner, melainkan

sebagai musuh dan penghambat pelaksanaan pembangunan nasional.

Adapun yang menjadi pertimbangan dikeluarkannya Keputusan Jaksa Agung No. KEP-
152/A/JA/10/2015 tanggal 1

Oktober 2015, yaitu:

a. Inpres No. 7 Tahun 2015 tentang Aksi Pencegahan dan Pemberantasan Tindak Pidana Korupsi, yang antara lain mengedepankan pentingnya upaya-upaya pencegahan terjadinya tindak pidana korupsi di instansi pemerintah.

b. Pidato Presiden RI pada Hari Bhakti Adhyaksa tanggal 22 Juli 2015, yang menekankan pemberantasan korupsi danpenegakan hukum harus diletakkan untuk tujuan meningkatkan kesejahteraan rakyat dengan menjaga kelancaran program pembangunan yang berkenaan dengan itu, Kejaksaan Republik Indonesia perlu memberikan pendampingan kepada pejabat pemerintah terkait dalam hal akselerasi pembangunan dan program-program strategis pembangunan nasional;

c. Kejaksaan Republik Indonesia sebagai lembaga penegak hukum berperan mendukung keberhasilan penyelenggaraan pemerintahan dan pembangunan di pusat maupu daerah melalui pengawalan dan pengamanan baik dalam kegiatan perencanaan, pelaksanaan maupun pemanfaatan hasil pembangunan, termasuk dalam upaya mencegah timbulnya penyimpangan dan kerugian Negara;

Salah satu landasan yuridis dikeluarkannya Kepja No. 152 Tahun 2015 adalah Undang-Undang No. 30 Tahun 2014 tentang Administrasi Pemerintahan.

Tugas dan fungsi TP4 sebagaimana tertuang di dalam Keputusan Jaksa Agung No. KEP152/A/JA/10/2015 tanggal 1 Oktober 2015, yaitu: 
a. Mengawal, mengamankan dan mendukung keberhasilan jalannya pemerintahan dan pembangunan melalui upayaupaya pencegahaan /preventif dan persuasif di tingkat pusat dan daerah sesuai wilayah hukum penugasan masingmasing dengan cara:

1. Memberikan penerangan hukum di lingkungan instansi pemerintah, BUMN, BUMD dan pihak lain terakit materi tentang perencanaan, pelelangan, pelaksanaan pekerjaan, pengawasan pelaksanaan pekerjaan, perijinan, pengadaan barang dan jasa, tertib administrasi dan tertib pengelolaan keuangan Negara.

2. Melakukan diskusi atau pemabahasan bersama instansi pemerintah, BUMN, BUMD untuk mengidentifikasi permasalahan yang dihadapi dalam penyerapan anggaran dan pelaksanaan pembangunan;

3. Memberikan penerangan dan penyuluhan hukum, baik atas inisiatif TP4 maupun atas permintaan pihak-pihak yang memerlukan, yang tempat dan waktu pelaksanaannya ditetapkan berdasarkan kesepakatan dan sesuai kebutuhan;

b. Dapat memberikan pendampingan hukum dalam setiap tahapan program pembangunan dari awal sampai akhir, berupa:

1. Pembahasan hukum dari sisi penerapan regulasi, peraturan perundangundangan, mekanisme dan prosedur dengan pejabat pengelola anggaran atas permasalahan yang
dihadapi dalam hal
penyerapan anggaran;

2. Pendapat hukum dalam tahapan perencanaan, pelelangan, pelaksanaan, pengawasan pelaksanaan pekerjaan dan pengadaan barang/jasa, baik atas inisiatif TP4 maupun atas permintaan instansi dan pihak-pihak yang memerlukan;

c. Melakukan koordinasi di tingkat pusat dengan Aparat Pengawasan Intern Pemerintah untuk mencegah terjadinya penyimpangan yang berpotensi menghambat, menggagalkan dan menimbulkan kerugian Negara;

d. Bersama-sama melakukan monitoring dan evaluasi pelaksanaan pekerjaan dan program pembangunan;

e. Melaksanakan penegakan hukum represif ketika ditemukan bukti permulaan yang cukup setealah dilakukan koordinasi dengan Aparat Pengawasan Intern Pemerintah tentang telah terjadinya perbuatan melawan hukum, penyalahgunaan wewenang dan/atau perbuatan lainnya yang menimbulkan kerugian keuangan Negara

Dalam rangka melaksanakan Kepja No. 152 Tahun 2015 tentang Pembentukan TP4, Jaksa Agung memandang perlunya memberikan instruksi kepada para Jaksa Agung Muda dan Kepala Badan Diklat, Kepala Kejaksaan Tinggi dan Kepala Kejaksaan Negeri seluruh Indonesia, khususnya untuk mendukung keberhasilan penyelenggaraan pemerintahan dan pembangunan nasional di pusat dan daerah. Instruksi Jaksa Agung RI Nomor: 
001/A/JA/10/2015 tentang

Pembentukan dan Pelaksanaan

Tugas Tim Pengawal dan

Pengaman Pemerintahan dan

Pembangunan Pusat dan

Daerah Kejaksaan Republik

Indonesia memerintahkan

kepada:

1. Jaksa Agung Muda Intelijen, Jaksa Agung Muda Tindak Pidana Khusus dan Jaksa Agung Muda Perdata dan Tata Usaha Negara untuk :

a. Bertindak sebagai pengarah dan pengendali terhadap pelaksanaan kegiatan Tim Pengawal dan Pengaman

Pemerintahan dan Pembangunan Pusat (TP4P);

b. Menugaskan personil pada jajarannya untuk menjadi anggota TP4P;

c. Apabila dipandang perlu, dapat menambah keanggotaan Sub Tim.

2. Kepala Badan Pendidikan dan Pelatihan segera menyelenggarakan pendidikan dan pelatihan bagi para jaksa terutama dari bidang Intelijen, Bidang Tindak Pidana Khusus dan Bidang Perdata dan Tata Usaha Negara yang akan atau sedang ditugaskan sebagai anggota TP4P maupun TP4D, agar keagiatan pengawalan dan pengamanan kegiatan pembangunan dapat berlangsung efektif dan optimal.

3. Para Kepala Kejaksaan Tinggi untuk :
a. Bertindak
pengarah
sebagai
dan
pengendali terhadap pelaksanaan kegiatan
Tim Pengawal dan

Pengaman

Pemerintahan dan

Pembangunan Daerah

(TP4D) di tingkat

Provinsi;

b. Menugaskan personil pada jajarannya untuk menjadi anggota TP4D di tingkat Provinsi;

c. Apabila dipandang perlu, dapat menambah keanggotaan Sub Tim;

4. Para Kepala Kejaksaan Negeri untuk:

a. Bertindak sebagai

pengarah dan

pengendali terhadap

pelaksanaan kegiatan

Tim Pengawal dan

Pengaman

Pemerintahan dan

Pembangunan Daerah

(TP4D) di tingkat kabupaten/kota;

b. Menugaskan personil pada jajarannya untuk menjadi anggota TP4D di tingkat kabupaten/kota;

c. Apabila dipandang perlu, dapat menambah keanggotaan Sub Tim;

Mencermati ketentuan sebagaimana diatur Kepja No. 152 Tahun 2015 maupun Insja No. 001 Tahun 2015, maka sejatinya pembentukan TP4P/D merupakan pengejawantahan dari tugas dan wewenang Kejaksaan di bidang ketertiban/ dan ketentraman umum. Pasal 30 ayat (3) UndangUndang Nomor 16 Tahun 2004 tentang Kejaksaan Republik Indonesia, menyebutkan:

Dalam bidang ketertiban dan ketentraman umum, Kejaksaan turut meyelenggarakan keagiatan :

a. Peningkatan kesadaran hukum masyarakat ;

b. Pengamanan kebijakan penegakan hukum; 

c. Pengawasan peredaran barang cetakan;
d. Pengawasan kepercayaan yang dapat membahayakan masyarakat dan Negara;
e. Pencegahan penyalahgunaan dan/atau penodaan agama;
f. Penelitian dan pengenmbangan hukum serta statistik criminal.

Lebih lanjut ketentuan Pasal 34 Undang-Undang Kejaksaan disebutkan bahwa Kejaksaan dapat memberikan pertimbangan dalam bidang hukum kepada instansi pemerintah lainnya.

Pada sisi yang lain, sesungguhnya tugas dan fungsi TP4P/D merupakan pengembangan dari tugas dan fungsi Kejaksaan yang sudah ada selama ini, khususnya tugas dan fungsi di Bidang Intelijen serta Bidang Perdata dan Tata Usaha (Datun). Tugas dan fungsi Intelijen Kejaksaan meliputi kegiatan Intelijen Penyelidikan (Lid), Pengamanan (Pam) dan Penggalangan (Gal) untuk melakukan pencegahan tindak pidana untuk mendukung penegakan hukum baik preventif maupun represif. Salah satu tugas dan fungsi Intelijen yang relevan dengan TP4P/D, meliputi kegiatan penerangan dan penyuluhan hukum pada kelompok masyarakat atau lembaga lainnya yang dilakasanakan oleh Kejaksaan Tinggi, Kejaksaan Negeri dan Cabang Kejaksaan Negeri.

Sebagaimana yang ditentukan dalam Pasal 30 ayat (2) Undang-Undang Kejaksaan, bahwa di bidang Perdata dan Tata Usaha Negara Kejaksaan dengan kuasa khusus dapat bertindak di dalam maupun di luar pengadilan untuk dan atas nama negara atau pemerintah. Adapun ruang lingkup bidang Datun meliputi : bantuan hukum, pertimbangan hukum, penegakan hukum dan tindakan hukum lain.

Berdasarkan pemahaman tersebut di atas, maka sejatinya tugas dan fungsi TP4P/D merupakan implementasi dari kewenangan yang dimiliki kejaksaan dengan karakteristik khas. Kekhasan TP4P/D itu, setidaknya terlihat dari 2 (dua) karakteristik utamanya baik dilihat dari struktur tim maupun tugas dan fungsinya.

Pertama, adanya sinergitas dan keterpaduan dari ketiga bidang teknis Kejaksaan, yaitu bidang Intelijen, Datun dan bidang Pidsus. Keterpaduan dan sinergitas tersebut, nampak jelas dari struktur dan keanggotaan TP4 yang bersifat ex officio dari para pejabat struktural.

Keanggotaan TP4P terdiri dari: Direktur Pengamanan Pembangunan Strategis pada Jaksa Agung Muda Bidang Intelijen (Ketua), Direktur Pemulihan dan Perlindungan Hak (PPH) pada Jaksa Agung Muda Bidang Perdata dan Tata Usaha Negara (Wakil Ketua), Koordinator pada Jaksa Agung Muda Bidang Intelijen (Sekretaris), dengan keanggotaan meliputi Jaksa pada Bidang Intelijen, Jaksa pada Bidang Perdata dan Tata Usaha Negara dan Jaksa pada Bidang Tindak Pidana Khusus.

Adapun keanggotaan TP4D tingkat Provinsi, dimana Asisten Bidang Intelijen pada Kejaksaan Tinggi (Ketua), Asisten Bidang Perdata dan Tata Usaha Negara pada Kejaksaan Tinggi (Wakil Ketua), Kepala Seksi Pengamanan Pembangunan Strategis pada Asisten Bidang Intelijen (Sekretaris), dengan keanggotaan meliputi Jaksa pada Bidang Intelijen, Jaksa pada Bidang 
Perdata dan Tata Usaha Negara dan Jaksa pada Bidang Tindak Pidana Khusus di Kejaksaan Tinggi.

Keanggotaan TP4D Tingkat Kabupaten/Kotamadya meliputi Kepala Seksi Intelijen pada Kejaksaan Negeri (Ketua), Kepala Seksi Perdata dan Tata Usaha Negara pada Kejaksaan Negeri (Wakil Ketua), dengan keanggotaan meliputi Jaksa pada Bidang Intelijen, Jaksa pada Bidang Perdata dan Tata Usaha Negara dan Jaksa pada Bidang Tindak Pidana Khusus di Kejaksaan Negeri.

Kedua, adanya perluasan dari tugas dan fungsi yang memungkinkan Kejaksaan secara menyeluruh melakukan pendampingan dalam keagiatan/proyek pembangunan. Totalitas bentuk pendampingan dari TP4 mulai perencanaan, pelaksanaan sampai pada pemanfaatan hasil pembangunan, termasuk dalam upaya mencegah timbulnya penyimpangan dan kerugian negara Berbeda halnya dengan pendampingan yang dilakukan bidang Datun memlaui Memmorandum of Understanding (MoU) dan Surat Kuasa Khusus, biasanya terbatas sampai pada penandatangan kontrak dan Surat Perintah Kerja (SPK).

Begitupula halnya dengan perluasan fungsi bidang Intelijen, yang tidak saja terbatas pada program penyuluhan dan penerangan hukum secara konvensional. Melalui TP4P/D, bidang Intelijen menjalan fungsinya yang secara proaktif mealkukan pembahasan hukum dari sisi penerapan regulasi, termasuk meakanisme dan prosedur dengan pejabat pengelola anggaran atas permasalahan yang dihadapi dalam hal penyerapan anggaran.
Bentuk totalitas dari TP4 juga terlihat dari keterlibatan ketiga bidang teknis (bidang Intelijen, bidang Datun dan bidang Pidsus), yaitu bersatu padu melakukan pendampingan dan pengawalan terhadap suatu kegiatan/proyek pembangunan. Keterlibatan ketiga bidang teknis Kejaksaan menjadikan adanya kesinambungan antara preventif, preemtif, edukatif, persuasif dan apabila memungkinkan melalui pendekatan represif sebagai langkah terakhir.

Totalitas dan keterpaduan antar ketiga bidang teknis dalam wadah TP4P/D tersebut menjadikan tidak alasan lagi bagi pelaksana kegiatan/proyek untuk takut melaksanakan programprogram pembangunan. Tidak relevan pula apabila Pengguna Anggaran/Kuasa Pengguna Anggaran masih mengkhawatirkan untuk menyerap anggaran yang telah direncanakan dan deprogramkan dalam Daftar Isian Pelaksanaan Anggaran (DIPA). Oleh karenanya tidak heran, apabila banyak instansi pemerintah, kementrian/lembaga dan BUMN/BUMD yang memanfaatkan TP4P/D ketika melakukan kegiatan proyek pembangunan.

\section{KESIMPULAN DAN SARAN}

\section{A. Kesimpulan}

1. Dalam Pengaturan Hukum Tim Pengawal, Pengaman Pemerintahan dan Pembangunan Daerah (TP4D) Kejaksaan RI dapat membantu birokrasi dalam mengembangkan inovasi dan kreativitas dalam pembangunan Nasional. Pemberantasan korupsi dalam Penegakan Hukum Kejaksaan harus mendampingin 
pejabat pemerintahan untuk akselerasi pembangunan nasional.

2. Peran Kejaksaan Tim Pengawal, Pengaman Pemerintahan dan Pembangunan Daerah (TP4D) Penjelasan Undang-undang Nomor 16 Tahun 2014 Tentang Kejaksaan RI. Kejaksaan terlibat sepenuhnya dalam proses pembangunan, dengan turut menciptakan kondisi yang mendukung dan mengamankan pelaksanaan pembangunan dalam rangka mewujudkan masyarakat adil dan makmur berdasarkan Pancasila.

B. Saran

1. Diharapkan Upaya-upaya pencegahan dan tindakan administrasi dilakukan didalam bagian penegakan hukum.

2. Diharapkan pembentukan Tim Pengawal, Pengaman Pemerintahan dan Pembangunan Daerah TP4P/D merupakan tugas dan wewenang Kejaksaan di bidang ketertiban/ dan ketentraman umum dapat terlaksana

\section{DAFTAR PUSTAKA}

\section{A. Buku-buku}

Dewa, Muh. Jufri, Hukum Administrasi Negara Dalam Perspektif

Pelayanan Publik, Unhalu

Press, Kendari, 2011.

Hamdi, Muchlis, Otonomi

Daerah dan Pembangunan Wilayah

Perbatasan, Sambas,

Kalimantan Barat, 2005.

Mulyana, Asep N. Dimesi

Koruptif Kebijakan (Pejabat)

Publik, Madju, Medan, 2016.
Simamora, Sogar. Hukum

Kontrak: Kontrak Pengadaan

Barang dan Jasa Pemerintah di

Indonesiam, Wins \& Partners Law Firm dan LbJ, Surabaya, 2013.

Yahya, Marzuki dan Endah Fitri Susanti. Buku Pintar Pengadaan Barang dan Jasa Pemerintah. Laskar Aksara, Jakarta, 2012.

\section{B. Perundang-undangan}

Instruksi Presiden Nomor 7 Tahun 2015 tentang Aksi Pencegahan Dan Pemberantasan Korupsi

Tahun 2015

Undang - Undang Republik Indonesia No. 16 Tahun 2004 tentang

Indonesia.

$$
\text { Kejaksaan Republik }
$$

Peraturan Presiden RI Nomor 38 Tahun 2010 jo Peraturan Jaksa Agung

Nomor 009/A/JA/01/2011 tanggal 24 Januari 2011 tentang Organisasi dan Tata Kerja

Kejaksaan RI.Undang-Undang Dasar Negara Republik Indonesia Tahun 1945.

Instruksi Jaksa Agung Nomor: INS-001/A/JA/10/2015 tentang Pembentukan dan

Pelaksanaan Tugas Tim Pengawal, Pengaman Pemerintahan dan Pembangunan Pusat (TP4P) dan

Daerah

(TP4D).

Keputusan Jaksa Agung Republik Indonesia Nomor: KEP152/A/JA/10/ 2015 tentang

Pembentukan Tim Pengawal, Pengaman

Pemerintahan dan Pembangunan (TP4).

Lampiran Peraturan Presiden No. 3 Tahun 2014 tentang 
Percepatan

Pelaksanaan Proyek Strategis Nasional .

C. Sumber Lain

https://www.neliti.com/id/public ations/147271/tinjauan-yuridis-

tentang-

delik-berlanjut-dalam-

perkara-tindak-pidana-korupsi

http://kejaksaan.go.id Jaksa

Agung dan Kajati Hadiri

Pertemuan

dengan Presiden di

Istana Bogor.

Sambutan Jaksa Agung RI pada Pembukaan Rapat Kerja Teknis Bidang

Intelijen dan Bidang Tindak Pidana Khusus Tahun 2016, Sasana

Andrawina Kejaksaan Agung Ri, Jakarta, 21 Sepetember 2016.
Risalah Pengarahan Presiden

Kepada Seluruh Kepala

Kepolisian Daerah (Kapolda)

dan Kepala Kejaksaan Tinggi

(Kajati) 